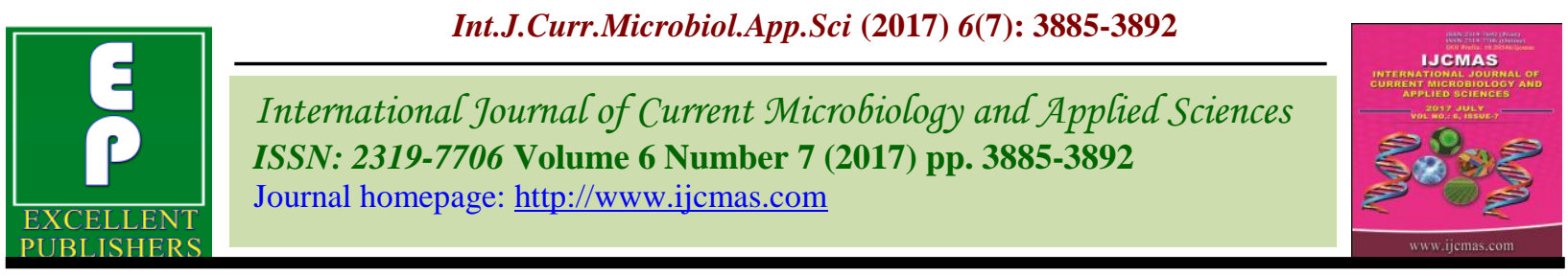

Original Research Article

https://doi.org/10.20546/ijcmas.2017.607.400

\title{
Effect of Arbuscular Mycorrhiza Fungi (AMF) on Early Seedling Growth of Some Multipurpose Tree Species
}

\author{
Naresh Kumar*, Anil Kumar, Ashok Shukla, Sudhir Kumar, \\ A.R. Uthappa and O.P. Chaturvedi \\ ICAR-Central Agroforestry Research Institute, \\ Near Pahuj Dam, Gwalior Road, Jhansi 284 003, Uttar Pradesh, India \\ *Corresponding author
}

\section{A B S T R A C T}

\begin{tabular}{|l|}
\hline Ke y w o r d s \\
Aegle marmelos, \\
Arbuscular Mycorrhiza \\
Fungi, Leucaena \\
leucocephala, Parkia \\
roxburghii, Seedling \\
quality index.
\end{tabular}

In present study, three important multipurpose tree species, namely Aegle marmelos, Leucaena leucocephala and Parkia roxburghii were inoculated with better performing native arbuscular mycorrhiza fungi (AMF) species of the region. The AMF species viz., Acaulospora scrobiculata and Rhizophagus irregularis were inoculated individually and in combination under nursery conditions. Study consisted of four treatments i.e. three mycorrhizal [individual inoculation (A. scrobiculata, $R$. irregularis) and combined inoculation (A. scrobiculata $+R$. irregularis)] and a control (un-inoculated). All mycorrhizal treatments (individual and combined) significantly increased plant height, collar diameter, shoot, root and total dry weights of seedlings over control, barring few exceptions. This can be due to more volume of soil exploration for available nutrients and water by mycorrhizal plants than non-mycorrhizal plants, which improves plant biomass. The mycorrhizal dependency (MD) for AMF inoculants ranged from 42.6 to $44.3 \%$ (mean MD: $43.3 \%$ ) in A. marmelos, -30.3 to $25.2 \%$ (Mean MD: $2.5 \%$ ) in L. leucocephala and 51.2 to $58.8 \%$ (mean MD: $55.5 \%$ ) in P. roxburghii. The seedling quality index, computed on the basis of growth parameters, also, showed that mycorrhizal treatments significantly improved plant heath. Thus, based on the results obtained from this study, we may expect a better establishment, survival and growth of the mycorrhizal inoculated seedlings in the fields.

\section{Introduction}

Arbuscular mycorrhiza fungi (AMF) are obligate symbionts that colonize the roots of most cultivated plant species (Kumar et al., 2007; Meddad-Hamza et al., 2010). Mycorrhizal symbiosis can be found in nearly all types of ecological situations and most plant species are able to form this symbiosis naturally (Jaizme-Vega et al., 2006; Shukla et al., 2012). These associations occur naturally in the fields, favoring plant development by increasing nutrient uptake, growth rates and hormonal activities (Shukla et al., 2010; Hashmi et al., 2010; Jha et al., 2012, 2014, 2015). The positive effects of mycorrhizae on seedlings survival and growth under nursery conditions are well documented (Smith et al., 2009; Guissou et al., 2016).

To develop any agroforestry/forestry model, healthy seedlings of woody perennials are pre-requisite (Jha et al., 2015). When the nursery raised seedlings are transplanted, they 
may face transplantation shocks in the fields and consequently plants become weaker and poorly established (Hartmann and Kester, 1986). Navarro-Garcia et al., (2011) postulated that preconditioning of young seedlings with efficient AMF not only makes plant stronger but also helps in their establishment in fields. Early inoculation of seedlings with AMF under nursery conditions can be beneficial in two ways i.e. superior and stronger growth of the seedlings, and better performance in the fields. But before going for AMF inoculation in nurseries, better understanding of the mycorrhizal system for tree species, nursery and out-planting site is required (Turjaman et al., 2008). Caravaca et al., (2003) suggested that native AMF species can produce more vigorous seedlings than non-native species. Moreover, several researchers have suggested that consortium of AMF species give better results in terms of growth as compared to individual AMF species (Jansa et al., 2008; Wehner et al., 2010; Shukla et al., 2014). However, Jansa et al., (2008) advocated that consortium of mycorrhizae, having multiple AMF species varies in competitive ability. Therefore, in present study, better performing native AMF species of the region (Acaulospora scrobiculata Trappe and Rhizophagus irregularis (Blaszk., Wubet, Renker \& Buscot) C. Walker \& A. Schüßler) were tested individually and in combination for their growth promotional activities under nursery conditions in important multipurpose tree species, namely Aegle marmelos (L.) Correa (Family: Rutaceae; Bael), Leucaena leucocephala (Lam.) de Wit (Family: Fabaceae; Subabul) and Parkia roxburghii G. Don (Fabaceae; Tree bean).

A. marmelos and L. leucocephala are being evaluated for their suitability in various agroforestry models at ICAR-Central Agroforestry Research Institute, Jhansi. $P$. roxburghii was also included in the study, as it is one of the important tree legumes (Firake et al., 2013). According to Rathi et al., (2012), $P$. roxburghii is known for its economic value as vegetable, medicinal, industrial and fire wood. It is a fast growing, easier to grow and hardy in nature. It is also being tested in agroforestry systems (Teklehaimanot, 2004).

\section{Materials and Methods}

The study was conducted at ICAR-Central Agroforestry Research Institute (CAFRI), Jhansi $\left(25^{\circ} 27^{\prime} \mathrm{N}\right.$ latitude, $78^{\circ} 35^{\prime} \mathrm{E}$ longitude and at $271 \mathrm{~m}$ above msl) during 2016-2017. On agro-ecological zone map of India, Jhansi lies in the hot semi-arid region. The area receives annual rainfall between 700 and $1150 \mathrm{~mm}$ mostly during South West monsoon period (Mid June-September) with an average of 52 rainy days per year. Mean maximum temperature ranges from $47.4^{\circ} \mathrm{C}$ (June) to $23.5^{\circ} \mathrm{C}$ (January) and mean minimum temperature from $27.2^{\circ} \mathrm{C}$ (June) to $4.1^{\circ} \mathrm{C}$ (December). Diurnal variation in temperature is quite high. May and June are the hottest months. The maximum recorded temperature on a particular day often touches $47-48{ }^{\circ} \mathrm{C}$ during summer.

Separate net house experiments were conducted for A. marmelos, L. leucocephala and $P$. roxburghii, to study the response of their seedlings to mycorrhizae fungi. Two AMF species, namely $A$. scrobiculata and $R$. irregularis were used individually and in combination, in the present study. Both species were selected on the basis of their relative abundance in our region and their ability to improve plant health (Hashmi et al., 2010; Jha et al., 2012; Shukla et al., 2016). A total of four treatments viz., A. scrobiculata (individual); $R$. irregularis (individual); $A$. scrobiculata $+R$. irregularis (combined) and control (un-inoculated seedlings) were employed in the study. Each treatment was 
replicated eight times in completely randomized design (CRD). Experiment was carried out in red soil (alfisol; pH: 6.29 (1:2.5 $\mathrm{H}_{2} \mathrm{O}$ ), EC: $134 \mu \mathrm{S} \mathrm{cm} \mathrm{cm}^{-1}$, organic carbon: $0.27 \%$, Olsen P: $2.5 \mathrm{ppm}$ ), collected from experimental farm of the institute. Mixture of red soil: sand: FYM (2:1:1) was used as potting substrate. Each polythene bag containing $3 \mathrm{~kg}$ substrate represented a unit. Treatments were imposed in the substrate by mixing mycorrhizal inocula with substrate @ $10 \mathrm{~kg}$ inoculum in $1000 \mathrm{~kg}$ substrate. For individual inoculations (either A. scrobiculata or $R$. irregularis), $10 \mathrm{~kg}$ inocula were mixed in $1000 \mathrm{~kg}$ substrate but for combined inoculation (A. scrobiculata $+R$. irregularis), $5 \mathrm{~kg}$ of each inoculum were mixed in $1000 \mathrm{~kg}$ substrate. This mycorrhiza-substrate mixture was filled in respective polythene bags. Surface sterilized seeds of A. marmelos, $L$. leucocephala and $P$. roxburghii were sown in the bags, and bags were transferred to nethouse and watered as and when required.
After germination, one healthy plant was maintained in each bag. After four month of sowing, the effect of mycorhizae inoculations were evaluated based on five morphological variables viz. plant height $(\mathrm{cm})$, measured with a ruler; collar diameter $(\mathrm{mm})$, measured by using a digital caliper; shoot dry weight (g), root dry weight (g) and total dry weight $\left(g_{\text { plant }}{ }^{-1}\right)$. Dry weights were determined, after drying the material in a hot air oven at $70{ }^{\circ} \mathrm{C}$ for $72 \mathrm{hrs}$. Mycorrhizal dependency (MD) was calculated in terms of plant growth as $[(\mathrm{M}-\mathrm{NM}) / \mathrm{M}] \times 100$, using dry weights of individual mycorrhizal plants (M) and mean dry weight of corresponding non-mycorrhizal (NM) plants (Plenchette et al., 1983). The data recorded on above mentioned morphological features of the seedlings were used to compute seedling quality parameters. The seedling quality index was, also, calculated by using the formula given by Dickson

(1960):

\section{Statistical analysis}

Data were subjected to analysis of variance using the ANOVA procedure of the Web Agri Stat Package developed by ICAR Research Complex Goa, India. Statistical significance was determined at the $5 \%$ probability level. Means were compared by applying Duncan's Multiple Range Test (DMRT).

\section{Results and Discussion}

In A. marmelos, all mycorrhizal treatments significantly increased plant height, collar diameter, shoot, root and total dry weights over control. Maximum plant height (16.4 $\mathrm{cm}$ ) was recorded in $R$. irregularis, followed
Total dry weight of plant (g)

$\frac{\text { Plant height }(\mathrm{cm})}{\text { Collar diameter }(\mathrm{mm})}+\frac{\text { Shoot dry weight }(\mathrm{g})}{\text { Root dry weight }(\mathrm{g})}$

by $A$. scrobiculata $(15.3 \mathrm{~cm})$ and $A$. scrobiculata $+R$. irregularis $(14.6 \mathrm{~cm})$. However, differences among mycorrhizal treatments for plant height, shoot, root and total dry weight were statistically nonsignificant. Maximum collar diameter (6.00 $\mathrm{mm}$ ) was recorded in $A$. scrobiculata which was comparable with $R$. irregularis and significantly superior to dual inoculation ( $A$. scrobiculata $+R$. irregularis). MD was recorded maximum (44.3\%) in $R$. irregularis which was at par with other mycorrhizal treatments (Table 1). In L. leucocephala, maximum plant height $(74.9 \mathrm{~cm})$ was recorded in $R$. irregularis which was at par with A. scrobiculata and significantly higher than combined inoculation. More or less 
similar results were obtained for shoot, root and total dry weight. Difference in various mycorrhizal treatments for collar diameter was statistically non-significant. MD was recorded maximum $(25.2 \%)$ in $R$. irregularis which was at par with $A$. scrobiculata (Table $2)$. In $P$. roxburghii, all the treatments significantly increased the studied parameters over control. Maximum plant height (59.7 $\mathrm{cm})$ was recorded in $R$. irregularis, followed by $A$. scrobiculata and A. scrobiculata $+R$. irregularis. Higher values of collar diameter $(8.6 \mathrm{~mm})$, shoot (14.88 g), root (4.56 g) and total dry weight (19.45 g) were recorded in $A$. scrobiculata-inoculated plants which were at par with $R$. irregularis. Maximum dependency for dry matter production in $P$. roxburghii (58.8\%) was recorded in $A$. scrobiculata which was at par with $R$. irregularis (Table 3). Thus, the results of present study showed that all mycorrhizal treatments (either individual or combined inoculation) increased growth of the test plant species when compared with un-inoculated. This could be due to more volume of soil exploration for available nutrients and water by mycorrhizal plants than non-mycorrhizal plants. Better nutrients, especially phosphorus and water uptake by AM-inoculated plants generally leads to secondary indirect effect such as improved plant biomass (Jha et al., 2012; Shukla et al., 2012). Beneficial effects of AM inoculation on growth and health of various plant species, including $A$. marmelos, L. leucocephala and Parkia species have been reported by several researchers (Habte and Fox 1989; Manjunath et al., 1989; Awotoye et al., 1992; Osundina 1995; Guissou et al., 1998; Schneider et al., 2013; Verma et al., 2015).

Table.1 Effect of arbuscular mycorrhizal fungi (AMF) inoculation on growth parameters of Aegle marmelos

\begin{tabular}{|l|c|c|c|c|c|c|c|}
\hline Treatment & \multirow{2}{*}{$\begin{array}{c}\text { Plant } \\
\text { height } \\
(\mathrm{cm})\end{array}$} & \multirow{2}{*}{$\begin{array}{c}\text { Collar } \\
\text { diameter } \\
(\mathrm{mm})\end{array}$} & \multicolumn{3}{|c|}{ Dry weight (g) } & MD & SQI \\
\cline { 4 - 7 } & & & & Root & Plant & & \\
\hline A. scrobiculata & $15.3^{\mathrm{a}}$ & $6.0^{\mathrm{a}}$ & $3.15^{\mathrm{a}}$ & $4.12^{\mathrm{a}}$ & $7.27^{\mathrm{a}}$ & $42.6^{\mathrm{a}}$ & $2.177^{\mathrm{a}}$ \\
\hline R. irregularis & $16.4^{\mathrm{a}}$ & $5.5^{\mathrm{a}}$ & $2.87^{\mathrm{a}}$ & $4.39^{\mathrm{a}}$ & $7.26^{\mathrm{a}}$ & $44.3^{\mathrm{a}}$ & $1.987^{\mathrm{a}}$ \\
\hline $\begin{array}{l}\text { A. } \text { scrobiculata }+ \\
\text { R. } \text { irregularis }\end{array}$ & $14.6^{\mathrm{a}}$ & $4.6^{\mathrm{b}}$ & $2.78^{\mathrm{a}}$ & $4.42^{\mathrm{a}}$ & $7.20^{\mathrm{a}}$ & $42.9^{\mathrm{a}}$ & $1.891^{\mathrm{a}}$ \\
\hline Un-inoculated & $9.8^{\mathrm{b}}$ & $3.3^{\mathrm{c}}$ & $1.64^{\mathrm{b}}$ & $2.32^{\mathrm{b}}$ & $3.96^{\mathrm{b}}$ & -- & $1.093^{\mathrm{b}}$ \\
\hline
\end{tabular}

Different letters within the column indicate significant differences

Table.2 Effect of arbuscular mycorrhizal fungi (AMF) inoculation on growth parameters of Leucaena leucocephala

\begin{tabular}{|c|c|c|c|c|c|c|c|}
\hline \multirow[t]{2}{*}{ Treatment } & \multirow{2}{*}{$\begin{array}{l}\text { Plant } \\
\text { height } \\
(\mathrm{cm})\end{array}$} & \multirow{2}{*}{$\begin{array}{l}\text { Collar } \\
\text { diameter } \\
(\mathrm{mm})\end{array}$} & \multicolumn{3}{|c|}{ Dry weight (g) } & \multirow{2}{*}{$\begin{array}{l}\mathrm{MD} \\
(\%)\end{array}$} & \multirow[t]{2}{*}{ SQI } \\
\hline & & & Shoot & Root & Plant & & \\
\hline A. scrobiculata & $74.8^{\mathrm{a}}$ & $7.5^{\mathrm{a}}$ & $8.41^{\mathrm{ab}}$ & $3.58^{\mathrm{ab}}$ & $11.99^{\mathrm{ab}}$ & $12.6^{\mathrm{a}}$ & $0.951^{\mathrm{a}}$ \\
\hline R. irregularis & $74.9^{\mathrm{a}}$ & $8.0^{\mathrm{a}}$ & $9.70^{\mathrm{a}}$ & $4.30^{\mathrm{a}}$ & $13.99^{\mathrm{a}}$ & $25.2^{\mathrm{a}}$ & $1.208^{\mathrm{a}}$ \\
\hline $\begin{array}{l}\text { A. scrobiculata }+ \\
\text { R. irregularis }\end{array}$ & $57.0^{\mathrm{b}}$ & $6.9^{\mathrm{a}}$ & $5.49^{b}$ & $2.38^{b}$ & $7.87^{b}$ & $-30.3^{b}$ & $0.746^{\mathrm{a}}$ \\
\hline Un-inoculated & $58.8^{b}$ & $7.0^{\mathrm{a}}$ & $6.28^{b}$ & $3.07^{\mathrm{ab}}$ & $9.35^{b}$ & -- & $0.894^{\mathrm{a}}$ \\
\hline
\end{tabular}

Different letters within the column indicate significant differences 
Table.3 Effect of arbuscular mycorrhizal fungi (AMF) inoculation on growth parameters of Parkia roxburghii

\begin{tabular}{|c|c|c|c|c|c|c|c|}
\hline \multirow[t]{2}{*}{ Treatment } & \multirow{2}{*}{$\begin{array}{l}\text { Plant } \\
\text { height } \\
(\mathrm{cm})\end{array}$} & \multirow{2}{*}{$\begin{array}{c}\text { Collar } \\
\text { diameter } \\
(\mathrm{mm})\end{array}$} & \multicolumn{3}{|c|}{ Dry weight (g) } & \multirow{2}{*}{$\begin{array}{l}\mathrm{MD} \\
(\%)\end{array}$} & \multirow[t]{2}{*}{ SQI } \\
\hline & & & Shoot & Root & Plant & & \\
\hline A. scrobiculata & $57.3^{\mathrm{a}}$ & $8.6^{\mathrm{a}}$ & $14.88^{\mathrm{a}}$ & $4.56^{\mathrm{a}}$ & $19.45^{\mathrm{a}}$ & $58.8^{\mathrm{a}}$ & $1.936^{\mathrm{a}}$ \\
\hline R. irregularis & $59.7^{\mathrm{a}}$ & $8.3^{\mathrm{ab}}$ & $14.36^{\mathrm{ab}}$ & $3.53^{\mathrm{ab}}$ & $17.89^{\mathrm{ab}}$ & $56.5^{\mathrm{a}}$ & $1.587^{b}$ \\
\hline $\begin{array}{l}\text { A. scrobiculata }+ \\
\text { R. irregularis }\end{array}$ & $54.4^{\mathrm{a}}$ & $7.8^{\mathrm{b}}$ & $12.73^{b}$ & $3.34^{b}$ & $16.07^{b}$ & $51.2^{\mathrm{b}}$ & $1.484^{\mathrm{b}}$ \\
\hline Un-inoculated & $29.9^{b}$ & $6.9^{c}$ & $5.70^{c}$ & $2.00^{\mathrm{c}}$ & $7.70^{c}$ & -- & $1.034^{\mathrm{c}}$ \\
\hline
\end{tabular}

Different letters within the column indicate significant differences

The results, also, showed that the dependency of test plant species for dry matter production on the inoculated fungi i.e. MD varied from 42.6 to $44.3 \%$ (mean MD: $43.3 \%$ ) in $A$. marmelos, -30.3 to $25.2 \%$ (Mean MD: $2.5 \%$ ) in L. leucocephala and 51.2 to $58.8 \%$ (mean MD: $55.5 \%$ ) in $P$. roxburghii. Further, results showed that plants inoculated with individual inoculants (either A. scrobiculata or $R$. irregularis) showed higher MD value than combined inoculation (A. scrobiculata $+R$. irregularis) in all studied plant species.

This could be due to functional compatibility between AMF and plant species (Genre and Bonfante, 2005). According to de Novais et al., (2014), different AMF species (even different strains of AMF) have different strategy for colonization of plant roots, which may be related to taxonomic differences at the family level. AMF species, having different mode of actions were included in the present study. A. scrobiculata forms veiscles inside root, spores outside the roots, does not produce sporocarps, etc. while $R$. irregularis produces vesicles, spores inside the roots and sporocarps (Shukla et al., 2010; Jha et al., 2014, 2015). This could explain the reason that why tested AMF species did not work synergistically with each other. It was postulated that there may be a preference for a particular AMF species by studied plant species. Seedling quality index computed on the basis of growth parameters suggested that in A. marmelos, all treatments significantly improved its quality, wherein maximum seedling quality index (2.177) was recorded in A. scrobiculata-inoculated plants, followed by $R$. irregularis and combined inoculation $(A$. scrobiculata $+R$. irregularis). In $L$. leucocephala, it was recorded maximum (1.208) in $R$. irregularis, followed by $A$. scrobiculata.

In $P$. roxburghii, all the treatments significantly improved the seedling quality, wherein maximum seedling quality index (1.936) was recorded in A. scrobiculatainoculated plants, followed by $R$. irregularis.

Thus, from present study it is concluded that the seedling quality parameters of all the tested plant species have been improved, when they were inoculated with AMF under nursery conditions. Thus, we may expect a better establishment, survival and growth of these AM-inoculated seedlings in the fields after out planting.

\section{Acknowledgement}

Authors are thankful to the Director, ICARCAFRI, Jhansi, India for facilitating the research program and constant encouragement during the study. 


\section{Conflict of interest}

Authors declared that there is no conflict of interest.

\section{References}

Awotoye, O.O., Atayese, M.O., Osonubi, O., Mulongoy, K., Okali, D.U.U. 1992. Response of some tropical nitrogenfixing woody legumes to drought and inoculation with mycorrhiza. In: Mulongoy, K., Gueye, M., Spencer, D.S.C. (Eds.), Biological Nitrogen Fixation and Sustainability of Tropical Agriculture. Wiley and Sayce, Glouchester, New York. pp. 67-77.

Ba, A.M., Plenchette, C., Danthu, P., Duponnois, R., Guissou, T. 2000. Functional compatibility of two arbuscular mycorrhizae with thirteen fruit trees in Senegal. Agroforest. Syst., 50(2): 95-105.

Caravaca, F., Barea, J.M., Palenzuela, J., Figueroa, D., Alguacil, M.M., Roldan, A. 2003. Establishment of shrub species in a degraded semiarid site after inoculation with native or allochthonous arbuscular mycorrhizal fungi. App. Soil Ecol., 22: 103-111.

de Novais, C.B., Borges, W.L., Jesus, E.D., Saggin, O.J., Siqueira, J.O. 2014. Interand intraspecific functional variability of tropical arbuscular mycorrhizal fungi isolates colonizing corn plants. App. Soil Ecol., 76: 78-86

Dickson, A., Leaf, A.L., Hosner, J.F. 1960. Quality appraisal of white spruce and white pine seedling stock in nurseries. Forest. Chron., 36: 10-13.

Firake, D.M., Venkatesh, A., Firake, P.D., Behere, G.T., Thakur, N.S.A. 2013. Parkia roxburghii: An underutilized but multipurpose tree species for reclamation of jhum land. Curr. Sci., 104(12): 1598-1599.
Genre, A., Bonfante, P. 2005. Building a mycorrhizal cell: How to reach compatibility between plants and arbuscular mycorrhizal fungi. J. Plant Interact., 1(1): 3-13.

Guissou, T., Ba, A.M., Ouadba, J.M., Guinko, S., Duponnois, R. 1998. Responses of Parkia Benth, Tamarindus indica $\mathrm{L}$. and Zizyphus mauritiana Lam. to arbuscular mycorrhizal fungi in a phosphorus-deficient sandy soil. Biol. Fert. Soil, 26: 194-198.

Guissou, T., Babana, A.H., Sanon, K.B., Ba, A.M. 2016. Effects of arbuscular mycorrhizae on growth and mineral nutrition of greenhouse propagated fruit trees from diverse geographic provenances. Biotechnol. Agron. Soc. Environ., 20(3): 417-426.

Habte, M., Fox, R.L. 1989. Leucaena leucocephala seedling response to vesicular-arbuscular mycorrhizal inoculation in soils with varying levels of inherent mycorrhizal effectiveness. Biol. Fert. Soil, 8(2): 111-115.

Hartmann, H.T., Kester, D.E. 1986. Plant Propagation: Principles and Practices, 4th ed. New Delhi, India: Prentice Hall of India.

Hashmi S., Kumar A., Shukla A., Jha A. 2010. Response of four minor fruit tree seedlings to arbuscular mycorrrhizal inoculations. Indian J. Agri. Sci., 80: $551-554$.

Jaizme-Vega, M.C., Rodriguez-Romero, A.S., Núnez, L.A.B. 2006. Effect of the combined inoculation of arbuscular mycorrhizal fungi and plant growthpromoting rhizobacteria on papaya (Carica papaya L.) infected with the root-knot nematode Meloidogyne incognita. Fruits, 61: 151-162.

Jansa, J., Smith, F.A., Smith, S.E. 2008. Are there benefits of simultaneous root colonization by different arbuscular 
mycorrhizal fungi? New Phytol., 177: 779-789.

Jha, A., Kamalvanshi, M., Kumar, A., Chakravarty, N., Shukla, A., Dhyani, S.K. 2014. The effects of arbuscular mycorrhizal inoculations and cotyledon removal on early seedling growth of Pongamia pinnata. Turkish J. Bot. 38: 526-535.

Jha, A., Kumar, A., Shukla, A., Chakravarty, N. 2012. Response of four multipurpose tree species to arbuscular mycorrhizal inoculations. Indian Phytopathol., 65: 297-299.

Jha, A., Kumar, A., Shukla, A., Kamalvanshi, M., Chakravarty, N., Dhyani, S.K. 2015. Effects of arbuscular mycorrhizal inoculations and cotyledon removal on early seedling growth of Jatropha curcas L. Proc. National Acad. Sci. India Sec. B: Biol. Sci., DOI 10.1007/s40011-015-0617-7

Kumar, A., Shukla, A., Hashmi, S., Tewari, R.K. 2007. Effect of trees on colonization of intercrops by vesicular arbuscular mycorrhizae in agroforestry systems. Indian J. Agric. Sci., 77: 291298.

Manjunath, A., Hue, N.V., Habte, M. 1989. Response of Leucaena leucocephala to vesicular-arbuscular mycorrhizal colonization and rock phosphate fertilization in an Oxisol. Plant Soil, 114(1): 127-133.

Meddad-Hamza, A., Beddiar, A., Gollotte, A., Lemoine, M.C., Kuszala, C., Gianinazzi, S. 2010. Arbuscular mycorrhizal fungi improve the growth of olive trees and their resistance to transplantation stress. African $J$. Biotechnol., 9(8): 1159-1167.

Navarro-Garcia, A., Del Pilar Banon Arias, S., Morte, A., Snachez-Blanco, M.J. 2011. Effects of nursery preconditioning through mycorrhizal inoculation and drought in Arbutus unedo L. plants. Mycorrhiza, 21: 53-64. Osundina, M.A. 1995. Responses of seedlings of Parkia biglobosa to drought and inoculation with vesicular-arbuscular mycorrhiza. Nig. J. Bot., 8: 1-10.

Plenchette, C., Fortin, J.A., Furlan, V. 1983. Growth responses of several plant species to mycorrhizae in a soil of moderate P-fertility. I. Mycorrhizal dependency under field conditions. Plant Soil, 70: 199-209.

Rathi, R.S., Misra, A.K., Roy, S., Verma, S.K., Singh, S.K. 2012. Potential of a lesser known tree species Parkia roxburghii G. Don of north east India. Indian Forester, 138(5): 476-479.

Schneider, J., Labory, C.R.G., Rangel, W.M., Alves, E., Guilherme, L.R.G. 2013. Anatomy and ultrastructure alterations of Leucaena leucocephala (Lam.) inoculated with mycorrhizal fungi in response to arsenic-contaminated soil. $J$. Hazard. Mat., 262: 1245-1258.

Shukla, A., Dehariya, K., Vyas, D., Jha, A. 2014. Interactions between arbuscular mycorrhizae and Fusariumoxysporum $\mathrm{f}$. sp. ciceris: Effects on fungal development, seedling growth and wilt disease suppression in Cicerarietinum L. Arch. Phytopathol. Plant Prot. 48: 240-252.

Shukla, A., Kumar, A., Chaturvedi, O.P., Nagori, T., Kumar, N., Gupta, A. 2016. Efficacy of rhizobial and phosphatesolubilizing bacteria and arbuscular mycorrhizal fungi to ameliorate shade response on six pulse crops. Agroforest. Syst., DOI 10.1007/s10457-017-0070-0

Shukla, A., Kumar, A., Jha, A., Dhyani, S.K., Vyas, D. 2012. Cumulative effects of tree based intercropping on arbuscular mycorrhizal fungi. Biol. Fert. Soil, 48: 899-909.

Shukla, A., Kumar, A., Jha, A., Tripathi, V.D. 2010. Effect of soil moisture on growth and arbuscular mycorrhizalcolonization 
of crops and tree seedlings in alfisol. Indian Phytopathol., 63: 411-417.

Smith, S.E., Facelli, E., Pope, S., Smith, F.A. 2009. Plant performance in stressful environments: interpreting new and established knowledge of the roles of arbuscular mycorrhizas. Plant Soil, 326: $3-20$.

Teklehaimanot, Z. 2004. Exploiting the potential of indigenous agroforestry trees: Parkia biglobosa and Vitellaria paradoxa in sub-Saharan Africa. Agroforest. Syst., 61(1): 207-220.

Turjaman, M., Tamai, Y., Sitepu, I.R., Santoso, E., Osaki, M., Tawaraya, K. 2008. Improvement of early growth of two tropical peat-swamp forest tree species Ploiariumalternifolium and $\mathrm{Cal}$ ophyllum hosei by two arbuscular mycorrhizal fungi under greenhouse conditions. New Forest, 36: 1-12.

Verma, N.K., Tripathee, R., Chourasiya, S., Thakur, A.K. 2015. Effect of plant growth promoting microbes on bael (Aegle marmelos) seedlings in nursery. Indian Forest, 141(1): 79-82.

Wehner, J., Antunes, P.M., Powell, J.R., Mazukatow, J., Rillig, M.C. 2010. Plant pathogen protection by arbuscular mycorrhizas: a role for fungal diversity? Pedobiologia, 53: 197-201.

\section{How to cite this article:}

Naresh Kumar, Anil Kumar, Ashok Shukla, Sudhir Kumar, A.R. Uthappa and Chaturvedi, O.P. 2017. Effect of Arbuscular Mycorrhiza Fungi (AMF) on Early Seedling Growth of Some Multipurpose Tree Species. Int.J.Curr.Microbiol.App.Sci. 6(7): 3885-3892. doi: https://doi.org/10.20546/ijcmas.2017.607.400 